107 Royal Netherlands Institute for Sea Research

This is a postprint of:

Walles, B., Fodrie, F.J., Nieuwhof, S., Jewell, O.J.W., Herman, P.M.J. \& Ysebaert, T. (2016). Guidelines for evaluating performance of oyster habitat restoration should include tidal emersion: reply to Baggett et al. Restoration Ecology, 24(1), 4-7

Published version: $\underline{\text { dx.doi.org/10.1111/rec.12328/ }}$

Link NIOZ Repository: $\underline{w w w . v l i z . b e / e n / i m i s ? m o d u l e=r e f \& r e f i d=252508}$

[Article begins on next page]

The NIOZ Repository gives free access to the digital collection of the work of the Royal Netherlands Institute for Sea Research. This archive is managed according to the principles of the Open Access Movement, and the Open Archive Initiative. Each publication should be cited to its original source - please use the reference as presented.

When using parts of, or whole publications in your own work, permission from the author(s) or copyright holder(s) is always needed. 


\title{
Guidelines for evaluating performance of oyster habitat restoration should include tidal emersion: reply to Baggett et al.
}

\author{
Brenda Walles ${ }^{1}$, F. Joel Fodrie ${ }^{2}$, Sil Nieuwhof ${ }^{1}$, Oliver J.D. Jewell ${ }^{1}$, Peter M.J. Herman ${ }^{1}$, Tom \\ Ysebaert $^{1,3}$ \\ ${ }^{1}$ NIOZ Yerseke, Royal Netherlands Institute for Sea Research, Yerseke, The Netherlands \\ ${ }^{2}$ University of North Carolina at Chapel Hill, Institute of Marine Sciences, Morehead City, NC, U.S.A. \\ ${ }^{3}$ IMARES Wageningen, Institute for Marine Resources and Ecosystem Studies, Yerseke, The Netherlands
}

Author contributions: BW, FJF, SN, OJDJ, PMJH, TY conceived of and wrote the manuscript.

\begin{abstract}
Baggett et al. (2015) identified a set of three universal environmental variables to be monitored for evaluating all oyster habitat restoration projects: salinity, temperature and dissolved oxygen. Perhaps evidencing a bias towards subtidal reefs, this set of parameters omits another first-order environmental factor, tidal emersion. Intertidal oyster reefs can be the dominant reef habitat in estuaries, with clear zonation in oyster performance across the intertidal exposure gradient. Therefore, we propose to include tidal emersion as a fourth universal environmental parameter when designing and evaluating oyster restoration projects to better encompass the whole environmental spectrum along which reefs occur.
\end{abstract}

Key words: Crassostrea gigas, Crassostrea virginica, intertidal, reef performance, subtidal, tidal emersion, vertical zonation.

\section{Implications for Practice}

- Tidal emersion should be incorporated into environmental models of oyster habitat suitability to inform restoration guidelines that are more generically applicable across micro-, meso- and macro-tidal systems.

- Reef development and subsequent ecosystem service delivery are regulated by tidal emersion in most intertidal habitats.

- Subtidal and intertidal reef restoration activities can inform one another, but these reef types only rarely co-occur in the same location, largely due to the interactive effects of salinity and tidal emersion.

Monitoring restoration projects is essential to evaluate the success of restoring degraded ecosystems. Thus, we read with interest and appreciation Baggett et al. (2015), as they suggest a common set of metrics with standardized techniques for judging oyster habitat restoration efficacy regardless of initial project goal(s). As oyster reef construction is a rapidly growing field within restoration ecology, such a "lingua franca" is important from a practitioners point of view as it allows better evaluation of individual projects, but also enables scientists to draw comparisons 
among diverse projects and environmental contexts. This working group with experience in designing and monitoring oyster reef projects recommends to monitor a set of four universal metrics (reef areal dimensions, reef height, oyster density, and oyster size-frequency distribution) and a set of three universal environmental variables (water temperature, salinity, and dissolved oxygen). We support these three environmental parameters as dominant drivers of trends in universal metrics and oyster reef performance for subtidal reefs as proposed by Baggett et al. (2015). This set of parameters, however, omits another first-order environmental factor, i.e. tidal emersion. Conditions in the intertidal zone are different from the subtidal, leading to possible different distribution of oyster reefs within a coastal or estuarine system. Within the intertidal zone, settlement, growth and survival differ along the gradient from low to high intertidal, influencing oyster reef performance. We argue that tidal emersion should be included into the set of universal environmental parameters when designing and evaluating the performance of oyster habitat restoration projects. We demonstrate this with examples from Europe and the US.

Oyster reefs occur both subtidally and intertidally, but depending on the species and the prevailing abiotic and biotic conditions, intertidal oyster reefs can be the dominant reef habitat locally or regionally. For instance, eastern oysters, Crassostrea virginica, occupy the intertidal zone within higher-salinity portions of estuaries along the Mid-Atlantic US, escaping from their "enemies" (predators, bioeroders, parasites) that thrive in the subtidal (Bahr \& Lanier, 1981). Only in more brackish environments, where these enemies are also less abundant, is $C$. virginica able to form subtidal reefs (Figure 1). Because areas with significant tidal amplitudes also regularly experience polyhaline-euhaline salinities, intertidal and subtidal reefs typically do not co-occur at local scales, but may at whole-estuary scales along meso- and macro-tidal coasts.

In contrast to $C$. virginica, Crassostrea gigas does occur both intertidally and subtidally within northern European estuaries (Diederich, 2005). Since $C$. gigas relatively recently invaded these European estuaries, a low predation pressure could be the reason they co-occur at local scales, whereas the native $C$. virginica population needs refugia from their "enemies" along either salinity (as highlighted by Baggett et al., 2015) or tidal emersion axes (Johnson \& Smee, 2014).

The importance of tidal emersion in the ecology of intertidal oyster reefs was well understood before the beginning of the $20^{\text {th }}$ century (reviewed in Bahr \& Lanier, 1981). Indeed, intertidal zonation in oyster fitness resulting from vertical gradients in settlement, competition, predation, pests (e.g., bioeroders), and disease was thoroughly investigated even prior to marine community ecologists famously highlighting the interplay of those dynamics along rocky shores. Consider the following cases that highlight the role of tidal emersion in natural and restored oyster reef performance and development in the intertidal zone.

Natural intertidal reefs of $C$. gigas occur from the low intertidal up to 55\% tidal emersion time in the Oosterschelde (SW Netherlands), 50\% tidal emersion time in the Wadden Sea (NW, Netherlands) (Walles, 2015) and 55\% in the Westerschelde (SW Netherlands, unpublished data). In the Oosterschelde estuary a manipulative field study showed that recruitment, growth, survival and condition index of oysters (C. gigas) is related to tidal emersion (Figure 2), with highest recruitment around 36\% emersion and highest condition index around 20\% emersion (Walles, 2015). Placement of artificial $C$. gigas reefs across a tidal emersion gradient (23-50\%) in the Oosterschelde showed that reefs constructed at the upper boundary failed to become selfsustainable (Walles, 2015; Walles et al., 2016). 
Experimental restoration in North Carolina (US) revealed lower vertical limits in the efficacy of oyster (C. virginica) restoration (Fodrie et al., 2014), analogous to the work in the Netherlands on upper vertical limits. Despite settlement rates of oysters in NC that were an order-of-magnitude higher on subtidal and low intertidal reefs, reefs that developed best and supported the highest densities of adult oysters (by over an order of magnitude) were constructed in the mid intertidal zone (Fodrie et al., 2014).

From completely immersed to completely emersed, oyster density and growth, for both $C$. gigas and $C$. virginica, follow a unimodal curve defined by a lower boundary, upper growth ceiling (for individual oysters and whole reefs), and an optimal growth zone identifiable between 20-40\% emersion during the average tidal cycle (Ridge et al., 2015; Walles, 2015). Therefore, oyster performance depends directly on tidal emersion which broadly influences reef areal dimensions, reef height, oyster density, and oyster size-frequency distribution (e.g., Rodriguez et al., 2014; Walles et al., 2015). Practically, tidal emersion is also a crucial factor for standardizing quadratbased data among sites and projects as quadrats may represent a range of tidal emersions even across a single reef (Ridge et al., 2015; Walles et al., 2016).

Unfortunately, the restriction of oysters to the intertidal zone in the high-salinity portions of eastern US estuaries has often been ignored in recent oyster enhancement and restoration efforts. Where reefs would be submerged during most of the tidal cycle and salinities are high, this oversight relative to tidal emersion can lead to significant underperformance or failures (e.g., Ocracoke and Clam Shoal Oyster Spawning Sanctuaries in North Carolina (NC), U.S.A., J. Fodrie personal observations). Failure to include the effect of tidal emersion in guidelines of reef restoration is also troubling given the recent emphasis on building oyster reef sills along eroding shorelines as a natural alternative to hard walls (sensu, Gittman et al., in press). If these oyster reef sills are sited subtidally in the lower, saltier sections of US mid-Atlantic estuaries, our observations indicate that they will not support viable oyster populations as intended to buffer shores against sea-level rise (Ridge et al., 2015), even though dissolved oxygen and, in temperate latitudes, temperatures rarelyif-ever approach the physiological limits of oysters.

There are also several obvious links between tidal emersion and functional performance metrics to evaluate natural or restored intertidal oyster reefs. For example, changes in tidal emersion per se, as well as changes in oyster density (a structural proxy of performance in many instances) as a function of emersion, affect the rates of denitrification supported by reefs (sensu Smyth et al., 2015). Relatedly, depth of tidal emersion over reefs likely impacts access to reefs for large mobile predators such as Sciaenops ocellatus and Sphyrna tiburo, which constrains both the habitat service provided by oyster reefs as well as the potential for top-down (i.e., cascading) community regulation (Byers et al., 2015).

"The oyster habitat restoration monitoring and assessment handbook" (Baggett et al., 2014) includes vertical position of reefs related to tide as a descriptive variable between different restoration projects. To create a more inclusive framework that can be used across systems dominated by either subtidal or intertidal reefs, we propose expanding the list of key environmental variables that are broadly applied to reef restoration to include tidal emersion (Table 1). When designing or evaluating oyster restoration projects, the interplay between salinity, temperature, dissolved oxygen and tidal emersion should be considered, together with the biological processes 
that go along with them. This requires a thorough understanding of the ecosystem under consideration, as well as the life history traits of the targeted oyster species.

\section{Acknowledgements}

This response paper was carried out as part of the EMERGO project, which is funded by the Building with Nature program of the NWO division for the Earth and Life Sciences (ALW 850.13.020). J. Fodrie was supported by funding from the NC Marine Resources Fund and the National Science Foundation (OCE-1155628). S. Nieuwhof was supported by funding from the User Support Space Research program of the NWO division for the Earth and Life Sciences (ALW) in cooperation with the Netherlands Space Office (NSO) (ALW-GO-AO/11-35). Thanks to Justin Ridge for help creating Figure 1. We thank two anonymous reviewers for helpful comments.

\section{LITERATURE CITED}

Baggett LP, Powers SP, Brumbaugh RD, Coen LD, Deangelis BM, Greene J, Hancock B, and Morlock SM. (2014) Oyster habitat restoration monitoring and assessment handbook. Arlington, Virginia. $96 \mathrm{pp}$

Baggett LP, Powers SP, Brumbaugh RD, Coen LD, Deangelis BM, Greene JK, Hancock BT, Morlock SM, Allen BL, Breitburg DL, Bushek D, Grabowski JH, Grizzle RE, Grosholz ED, La Peyre MK, Luckenbach MW, Mcgraw KA, Piehler MF, Westby SR, and Zu Ermgassen PSE (2015) Guidelines for evaluating performance of oyster habitat restoration. Restoration Ecology 23:737-745

Bahr LM, and Lanier WP (1981) The eoclogy of intertidal oyster reefs of the South Atlantic coast: A community profile, Washington, DC

Byers JE, Grabowski JH, Piehler MF, Hughes AR, Weiskel HW, Malek JC, and Kimbro DL (2015) Geographic variation in intertidal oyster reef properties and the influence of tidal prism. Limnology and Oceanography 60:1051-1063

Diederich S (2005) Differential recruitment of introduced Pacific oysters and native mussels at the North Sea coast: coexistence possible? Journal of Sea Research 53:269-281

Fodrie FJ, Rodriguez AB, Baillie CJ, Brodeur MC, Coleman SE, Gittman RK, Keller DA, Kenworthy MD, Poray AK, Ridge JT, Theuerkauf EJ, and Lindquist NL (2014) Classic paradigms in a novel environment: inserting food web and productivity lessons from rocky shores and saltmarshes into biogenic reef restoration. Journal of Applied Ecology 51:13141325

Gittman RK, Peterson CH, Currin CA, Fodrie FJ, Piehler MF, and J.F. B Living shorelines can enhance the nursery role of threatened coastal habitats. Ecological Applications, DOI dx.doi.org/10.1890/14-0716.1

Johnson KD, and Smee DL (2014) Predators influence the tidal distribution of oysters (Crassostrea virginica). Marine Biology 161:1557-1564

Ridge JT, Rodriguez AB, Joel Fodrie F, Lindquist NL, Brodeur MC, Coleman SE, Grabowski JH, and Theuerkauf EJ (2015) Maximizing oyster-reef growth supports green infrastructure with accelerating sea-level rise. Scientific Reports 5:14785

Rodriguez AB, Fodrie FJ, Ridge JT, Lindquist NL, Theuerkauf EJ, Coleman SE, Grabowski JH, Brodeur MC, Gittman RK, Keller DA, and Kenworthy MD (2014) Oyster reefs can outpace sea-level rise. Nature Climate Change 4:493-497

Smyth AR, Piehler MF, and Grabowski JH (2015) Habitat context influences nitrogen removal by restored oyster reefs. Journal of Applied Ecology 52:716-725 
Walles B (2015) The role of ecosystem engineers in the eco-morphological development of habitats. Thesis Wageningen University

Walles B, Mann R, Ysebaert T, Troost K, Herman PMJ, and Smaal AC (2015) Demography of the ecosystem engineer Crassostrea gigas, related to vertical reef accretion and reef persistence. Estuarine Coastal and Shelf Science 154:224-233

Walles B, Troost K, Van Den Ende D, Nieuwhof S, Smaal AC, and Ysebaert T (2016) From artificial structures to self-sustaining oyster reefs. Journal of Sea Research 108:1-9

Table 1. Tidal emersion included in the universal environmental variables table of Baggett et al. (2015).

\begin{tabular}{|c|c|c|c|}
\hline Metric & Methods & Units & Frequency \\
\hline Water temperature & $\begin{array}{l}\text { Measure above substrate close to reef using in } \\
\text { situ instrumentation, a thermometer, or other } \\
\text { handheld instrumentation. }\end{array}$ & ${ }^{\circ} \mathrm{C}$ & $\begin{array}{l}\text { Continuous (preferred), } \\
\text { otherwise as often as possible }\end{array}$ \\
\hline Salinity & $\begin{array}{l}\text { Measure above substrate close to reef using in } \\
\text { situ instrumentation, a refractometer, or other } \\
\text { handheld instrumentation }\end{array}$ & $\begin{array}{l}\text { ppt or } \\
\text { psu }\end{array}$ & $\begin{array}{l}\text { Continuous (preferred), } \\
\text { otherwise as often as possible }\end{array}$ \\
\hline Dissolved oxygen (subtidal only) & $\begin{array}{l}\text { Measure above substrate close to reef using in } \\
\text { situ instrumentation or other handheld } \\
\text { instrumentation }\end{array}$ & $\mathrm{mg} / \mathrm{L}$ & $\begin{array}{l}\text { Continuous (preferred), } \\
\text { otherwise as often as possible }\end{array}$ \\
\hline Tidal emersion (intertidal only) & $\begin{array}{l}\text { Use bathymetry/topography maps, or measure } \\
\text { height on top of the reef using a dGPS } \\
\text { (converting elevation to emersion time) }\end{array}$ & $\%$ & $\begin{array}{l}\text { Preconstruction, within } 3 \\
\text { months postconstruction. } \\
\text { After events that could alter } \\
\text { reef morphology }\end{array}$ \\
\hline
\end{tabular}

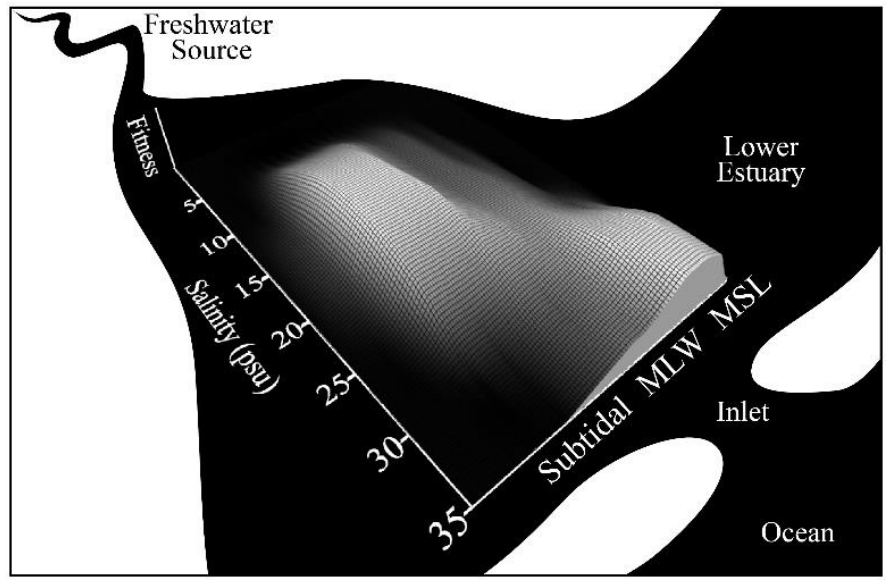

Figure 1. Conceptual model for C. virginica oyster reef fitness, along the mid-Atlantic of the US, as it relates to salinity, tidal emersion (relative elevation), and estuarine location based on authors' observations from Georgia and North Carolina. The salinity axis labels are approximations. MLW $=$ mean low water; MSL = mean sea level. In northern European estuaries, subtidal $(C$. gigas $)$ reefs can extend in to higher-salinity environments, perhaps due to the relative absence of predators (e.g., oyster drills), bioeroders (e.g., Cliona spp. sponge), and other pests. 


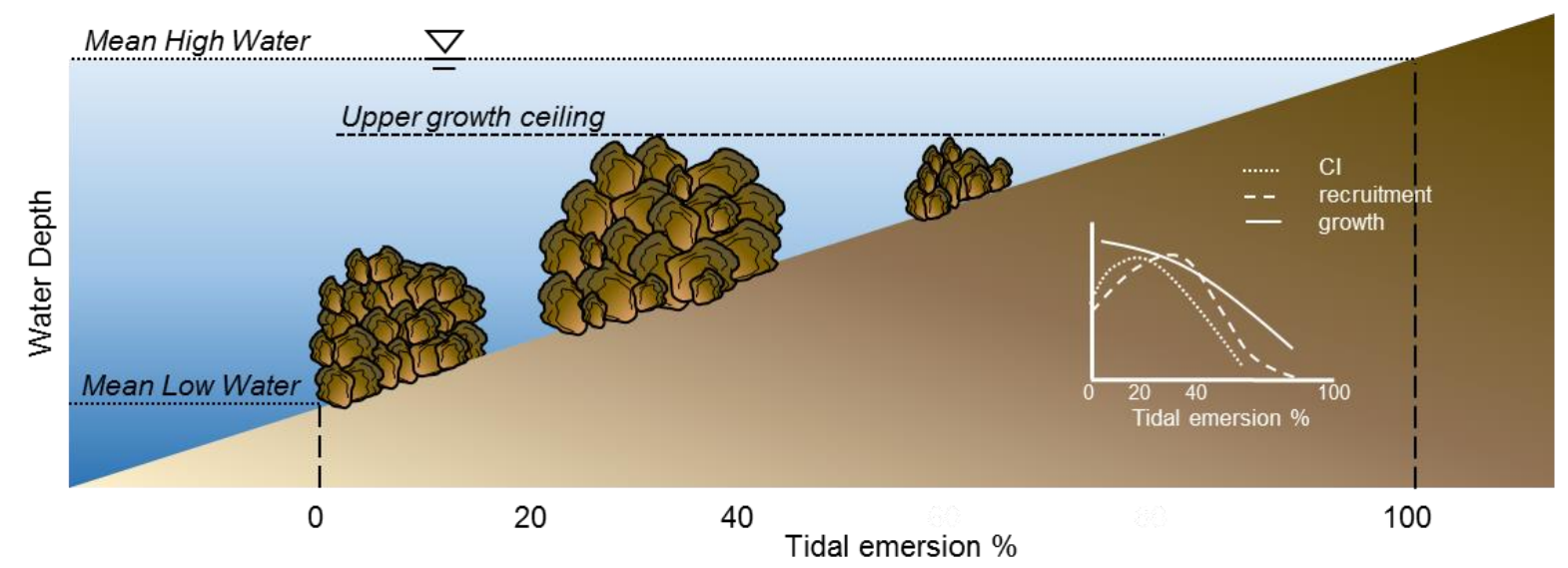

Figure 2. Conceptual model of oyster reef height (Crassostrea gigas) along a tidal emersion gradient in the intertidal zone. The maximum height reefs can reach depend on their location in the intertidal as well as an upper growth ceiling. Greatest individual growth occurs at short tidal emersion. The number of recruitment is highest around $36 \%$ tidal emersion. Condition index (CI) is highest around 20\% tidal emersion (Walles, 2015). 